\title{
RESIDENTIAL TREE PLANTING AND CARE: A STUDY OF ATTITUDES AND BEHAVIOR IN SACRAMENTO, CALIFORNIA
}

\author{
by Joshua Summit ${ }^{1}$ and E. Gregory McPherson ${ }^{2}$
}

\begin{abstract}
Site surveys were conducted on residential properties in Sacramento, California, and residents were given questionnaires about whether they had added trees to their properties, their motivations for planting trees, and the exient and frequency of their maintenance of the trees on their properties. These surveys indicate that most residents (68\% of the sample) plant trees on their properties; that residential areas are relatively densely planted (with room for about $9 \%$ more trees than are already in place); that issues of comfort (shade) and appearance play more of a role in the decision to plant trees than do concerns about energy savings, environmental benefit, or privacy; that tree planting tends to be greatest early in a resident's tenure in a home; and that convenience is a strong predictor of the types of tree maintenance provided by residents relative to that provided by contractors.
\end{abstract} policy

Keywords. Urban forestry; tree maintenance; public

Urban forestry has in the past focused on publicly owned land-primarily streets, parks, and greenbelt space. Indeed, the term "forestry" implies such a focus; it conjures images of large stands of trees that, in an urban setting, can be found only on tracts of land such as parks and greenbelts. Adding trees to public lands is simpler than attempting to increase the urban forest private yard by private yard. Foresting public lands often means convincing a few public officials of the importance and benefits of planting trees. Foresting private lands requires persuading hundreds or thousands of residents-people whose backgrounds rarely include ecology, economics, or tree planting. Little is known about the tree planting and maintenance habits of these residents. It is therefore no surprise that urban forestry has focused on planting trees on public lands.

The benefits of trees and natural environments are many. The addition of trees to an environment can improve it substantially: trees prevent erosion, cast shade, and provide protection from the elements. Trees can improve air quality by removing airborne pollutants and particulates (Smardon 1988; Nowak 1994), and they can significantly reduce household energy use through shading during summer months and reducing wind chill in fall and winter (Heisler 1986; Akbari et al. 1992; Nowak 1994; McPherson and Simpson 1995). In addition, people respond very positively to the presence of trees. City streets lined with trees are more favorably viewed by people than are streets without them (Schroeder 1989; Hull 1992) and receive more favorable quality of life evaluations (Sheets and Manzer 1991). Trees can increase the sense of attachment between individuals and the natural environment (Dwyer et al. 1992). People's desire for trees becomes evident when comparing the property values of lots with trees to those without (Relf 1981; Hull 1992), as well as in selfreported willingness to pay to visit parks with more dense concentrations of trees than those nearby (Heisler 1986).

The benefits of nature extend beyond the purely aesthetic. Ulrich $(1981,1984)$ reported health benefits as a result of exposure to nature, having mostly to do with reduced levels of stress and increased healing capacities. Stephen and Rachel Kaplan $(1987,1989)$ argue that exposure to natural environments restores the ability to focus attention after a person has become mentally exhausted. Appleyard (1980) points out that gardening-direct involvement with nature-is an important source of recreation for many people. Other authors have also documented benefits that accrue from involvement with nature (Relf 1981; Sommer et al. 1993; Nowak 1994; Summit and Sommer 1998).

Research on urban forestry has focused on how introducing trees into a neighborhood can affect the perception of the neighborhood by its residents, as well as how the planting process 
can affect patterns of social interaction (Sommer and Summit 1995; Summit and Sommer 1998). Such studies have reported positive effects resulting from involvement in tree planting. Tree planting also benefits the urban ecosystem by providing habitat and sustenance for wildlife, preventing erosion, moderating climate, and reducing pollution (Williamson 1973; Dwyer et al. 1992; Nowak 1994). Trees also serve an important role as design features in an urban area by defining a space, shaping how people behave in that particular area, and defining the relationship between the space and the buildings around it (Arnold 1980). The potential for elements of nature (most especially trees) to shape and improve city environments is considerable.

Urban forestry has largely focused on public land, in part because the challenges posed by "greening" public lands are less daunting than those posed by attempting the same with thousands of private homeowners. However, substantial benefits can be obtained from residential yard trees. Most people spend more time in and around their homes than in city parks and greenbelts; health and relaxation benefits from yard or street trees will be greater, in all likelihood, than from park trees. Energy benefits, for both the individual and the community, will likely also be greater when trees are planted in residential neighborhoods. In the city of Sacramento, $72 \%$ of all trees are on residential properties. McPherson (1994) simulated annual costs and benefits associated with proposed tree planting projects in Chicago. This study found that tree plantings in residential yards were a better investment than street, park, or highway plantings, returning an estimated $\$ 3.50$ for each dollar invested.

The task of reaching and involving homeowners is more challenging than the task of planting parks and greenbelts. It involves issues of attitude, motivation, knowledge of tree needs, and maintenance behavior. There is no office to contact when trying to convince a community to begin tree planting, no individual or small group of experts to win over. Instead, the argument in favor of tree planting must be made to individual homeowners and to neighborhood groups. Planting decisions regarding species and site selection must be tailored to each property and the wishes of each owner. This is a very labor-intensive process, but it builds stronger communities (Summit and Sommer 1998).

In an effort to achieve greater energy efficiency, the Sacramento Municipal Utility District (SMUD) joined in a partnership with the nonprofit Sacramento Tree Foundation to distribute free shade trees to homeowners. This effort is aimed at reducing air-conditioning energy needs of Sacramento to spare SMUD the expense of building another power plant to service the city.

One focus of the Sacramento Urban Forest Ecosystem Study was residential properties and tree planting. The research examined residents' motivation to plant trees, the extent and growth potential of Sacramento's urban forest, and the extent of maintenance behavior associated with yard and street trees. This information was gathered through inventories of residential properties (the numbers and types of trees on a property) and from questionnaires on maintenance behavior and planting/maintenance motivation that were distributed to residents during site visits.

\section{Research Objectives}

The objectives for this research were

1. to understand why people plant trees and, therefore, how to motivate people to plant more trees, as well as to discover which residents are likely to plant trees and where they obtained the trees they planted;

2. to develop a rough gauge of planting and tree removal rates across the time of a resident's tenure in a home;

3. to understand to what extent homeowners turn to commercial services for tree care, and what tree maintenance they perform themselves or leave undone;

4. to clarify the relationships between tree planting and tree care (i.e., whether people who undertake various forms of tree care are more likely to plant new trees); and

5. to develop an idea of the extent to which residential neighborhoods in Sacramento are forested, and the potential for growth of the Sacramento urban forest. 


\section{Method}

Residential properties in the city and county of Sacramento were surveyed to identify tree species and estimate size and condition of tree crowns. These physical inventories were supplemented by questionnaires distributed to residents, asking them about a wide variety of tree-care behaviors and services, as well as their motivations for tree planting and maintenance. The exact procedures will be discussed in three parts: site selection (for the physical inventory and questionnaire), the physical inventories themselves, and the questionnaires.

Site selection. Sites for the physical inventory were chosen from aerial photographs of Sacramento County. Gridded dots were placed on the photographic montage, and each dot was classified by land use. Dots that fell on residential land uses made up the population from which residences for the inventory were selected. Every third residence on which a dot fell was interpreted from the photographs to count existing trees and the potential for additional trees. Information on vegetation present on a piece of property was collected for 675 randomly selected properties. Of these 675,372 were one- to threefamily residential properties. All 372 residences were originally slated for inventory; of these, 242 residents $(65 \%)$ gave permission for a preliminary survey, and $133(36 \%)$ gave permission for the more extensive survey of the grounds around their property.

Physical inventory. With permission from the residents, researchers created comprehensive lists of the trees and shrubs on each property, noting as well the potential (if any) for addition of more trees. Specific note was made of the number, size, species, condition, and placement of trees on the property. Once this was done, researchers made two maps of the property, laying out the location of the house (and other structures on the property) and all trees and shrubs (all drawn roughly to scale). Potential locations for future trees were also noted on the maps. Researchers retained the map and attached a copy to the questionnaire distributed to residents.

Questionnaire. The questionnaire asked about a wide range of practices and motivational factors having to do with a resident's trees. Residents were asked about their degree of involvement in tree planting on their property, including how many trees they were responsible for having planted and how many they had planted with their own hands. They were asked about the maintenance done on the trees, how often it was done, and who did it (the resident or a service). Residents who had planted trees on their properties were also asked about their motives for adding trees. Finally, residents were asked to indicate on attached property maps which trees (if any) they wanted of the potential trees (if any) that were shown on the maps. These numbers indicate the potential expansion of the urban forest and a more realistic estimate of the likely expansion rate.

Questionnaires were distributed by hand to residents during the site visits, after researchers inventoried the properties; included with each questionnaire were a stamped return envelope and a letter explaining the project. Residents who did not return the questionnaire within approximately six to eight weeks received a follow-up letter with a new questionnaire and property map. Of 133 surveyed properties at which questionnaires were left, $80(60 \%)$ were returned. This high return rate is likely due to the large investment of time on the part of the researchers in surveying the property and the fact that residents, by agreeing to the physical inventory of the property, had committed themselves to the research project.

\section{Results}

Sampling checks. As a part of the site surveys, research assistants gathered data on the size of the property (which will be referred to as lot size), the size of the house on that property, the number of trees on the property, and the number of trees that could potentially be planted there. This information was available for respondents (people who returned the questionnaire) and nonrespondents alike. Analyses of variance were run comparing these two groups on the four variables. The groups did not differ significantly on lot area, $F(1,130)=$ $.58, P=.45$. They did, however, differ significantly on the other three variables. Respondents had larger homes $\left[201.9 \mathrm{~m}^{2}\right.$ vs. $159.3, F(1,130)=$ 
4.81, $P=.0301]$, more trees $[16.1$ vs. $9.9, F(1,130)$ $=8.81, P=.0036]$, and fewer potential trees [1.5 vs. $2.1, F(1,132)=8.02, P=.0054]$ than did nonrespondents. These differences between the groups raise some questions about generalization of results. The greater number of trees and the fewer unplanted (potential tree) sites found with respondents suggest that the people who returned our questionnaire may play a more active role in contributing to, and perhaps sustaining, the Sacramento urban forest.

Also in the questionnaire, residents were asked about themselves, their homes, and their tenure at their present location. These findings were then compared to the 1990 census records of the city of Sacramento to reveal how representative the sample gathered was. Three items were compared: median respondent age, median age of house, and median time of tenure. In the 1990 census, the median age of residents in the city of Sacramento was between 45 and 54 years; in our sample, it was 50 years. The median house age, in the census, was between 26 and 35 years; it was 32 years in our sample. The only considerable difference between the two was in median age of tenure, from two to five years for the census and 14 years among the questionnaire respondents. This difference is likely because the census data on tenure, as available to us, was not parsed into renters and owners, whereas our sample was almost exclusively owners (four renters of 80 respondents). Because renters move more frequently than homeowners, and because renters were represented in greater numbers in the census data than in our sample, the median tenure for renters would be expected to be greater than that of the homeowners. The presence of renters might also be expected to lower the average resident age in the census data compared to that found in our survey, but the two matched up rather well. The effect of renters' presence on the census data is harder to predict regarding house age, but here again, our figures and the census figures were in general agreement. By two measures, at least, our sample seemed to bear a resemblance to the overall population of the city of Sacramento.
Tree planting. The site surveys showed an average of 16.3 trees per property (with a standard deviation of 13.2 trees). Among respondents who reported sources for their trees (63 of 80 ), the most commonly reported source for those trees was a nursery $(41 \%)$; the next most common source was a previous owner $(30 \%$ of the trees were not planted by the current resident), followed by developers (4\%) and the Sacramento Tree Foundation (4\%), a nonprofit organization that distributes shade trees to reduce energy use and improve the environment of the Sacramento region. In addition, $19 \%$ of the trees reported in the survey came from other sources (such as gifts from friends). Of the 77 people who answered the question, $52(68 \%)$ had added trees to their property. The rate of tree planting showed a general decline over a resident's tenure (Table 1). Of the 52 residents who planted trees, 50 planted at least one of those trees themselves, as opposed to contracting with a service to have it planted professionally.

Respondents consistently reported that shade and aesthetics played a very large role in the decision to add a tree to their property, with shade being slightly more important. Energy savings, ecological benefit, privacy, and property value seemed to contribute less to that decision (Table 2).

Tree removal. Equally important as the issue of tree planting, for the urban forest, is the issue of tree removal. Of the 79 respondents, approximately $66 \%$ had removed at least one tree. The average number of removed trees was 2.3 (with a standard deviation of 3.2). The predominant reason for removing trees was that they were

Table 1. Tree planting and removal rates across tenure.

\begin{tabular}{lcc}
\hline Length of tenure & $\begin{array}{l}\text { Planting rate } \\
\text { (trees/year) }\end{array}$ & $\begin{array}{l}\text { Removal rate } \\
\text { (trees/year) }\end{array}$ \\
\hline $0-5$ years $(n=24)$ & 1.26 & 0.43 \\
$6-10$ years $(n=7)$ & 0.52 & 0.15 \\
$11-15$ years $(n=11)$ & 0.84 & 0.28 \\
$16-20$ years $(n=6)$ & 0.45 & 0.19 \\
$21-25$ years $(n=7)$ & 0.16 & 0.07 \\
$26-30$ years $(n=5)$ & 0.29 & 0.10 \\
$31+$ years $(n=11)$ & 0.31 & 0.08 \\
\hline
\end{tabular}


Table 2. Motivation for adding trees to property.

\begin{tabular}{lccc}
\hline Motivation & $\begin{array}{c}\text { Mean } \\
\text { rank }^{\mathrm{a}}\end{array}$ & $\begin{array}{c}\text { Standard } \\
\text { deviation }\end{array}$ & $\begin{array}{c}\text { No. of people } \\
\text { listing it as a } \\
\text { reason to plant }\end{array}$ \\
\hline Shade & 1.73 & 1.1 & 41 \\
Aesthetics & 1.8 & 1 & 46 \\
Other reason & 1.8 & 1.3 & 15 \\
\multicolumn{2}{l}{ (usually to obtain fruit) } & & 32 \\
Energy savings & 3 & 1.7 & 27 \\
Ecological benefit & 3.7 & 1.8 & 26 \\
Privacy & 3.81 & 1.81 & 26 \\
Property value & 3.96 & 1.87 & \\
\hline
\end{tabular}

a 1 = most important.

dead or dying (reported by 31 respondents, $61 \%$ of households). Root problems and size problems (trees being too large) were each cited by $20 \%$ of households, followed by the messiness of the trees or their tendency to draw insects $(16 \%$ of households, in each case). A variety of other problems was cited by $18 \%$ of households.

The average planting rate (number of trees planted per year) consistently exceeded the average tree removal rate (Table 1). This can be seen across years in residence (Figure 1). Across the entire range of tenure, the rate of tree planting was higher than the rate of tree removal.

Respondents removed 88 trees themselves, compared to 84 trees that were removed by tree services. Residents tended to remove smaller



Figure 1. Average planting and removal rates by number of years in residence.
Table 3. Trees removed, pruned, and treated for insects or disease by residents and by professionals.

\begin{tabular}{|c|c|c|c|c|c|c|}
\hline \multirow[b]{2}{*}{$\begin{array}{l}\text { Tree } \\
\text { height }\end{array}$} & \multicolumn{2}{|c|}{ No. trees removed } & \multicolumn{2}{|c|}{ No. trees pruned } & \multicolumn{2}{|c|}{ No. trees sprayed } \\
\hline & $\begin{array}{c}\text { by } \\
\text { residents }\end{array}$ & $\begin{array}{c}\text { by } \\
\text { experts }\end{array}$ & $\begin{array}{l}\text { by } \\
\text { residents }\end{array}$ & $\begin{array}{c}\text { by } \\
\text { experts }\end{array}$ & $\begin{array}{l}\text { by } \\
\text { residents }\end{array}$ & $\begin{array}{l}\text { by } \\
\text { experts }\end{array}$ \\
\hline $0-10 \mathrm{ft}$ & 21 & 1 & 39 & 20 & 30 & 3 \\
\hline $11-20 \mathrm{ft}$ & 38 & 26 & 115 & 41 & 34 & 1 \\
\hline $21-30 \mathrm{ft}$ & 17 & 19 & 41 & 50 & 25 & 14 \\
\hline $30-50 \mathrm{ft}$ & 12 & 25 & 14 & 46 & 3 & 28 \\
\hline $51+\mathrm{ft}$ & 0 & 20 & 0 & 24 & 0 & 5 \\
\hline
\end{tabular}

trees, while contracting to have larger ones removed by professionals. This relationship is presented in Table 3.

Tree maintenance. Maintaining a healthy urban forest requires a variety of behaviors and a significant investment of time and/or money. Because a very large portion of the urban forest in any city is on private land, the actions of individual homeowners, taken as a whole, will have a considerable impact on the urban forest, and so indirectly on the health and climate of the community. Important maintenance behaviors include the pruning of tree branches and pest management (usually by spraying trees with pesticides or anti-disease agents).

Of our respondents, $85 \%$ had their trees pruned or pruned them themselves. Reasons for pruning included maintaining tree health $(63 \%)$, keeping branches out of the way $(61 \%)$, ensuring safety (56\%), and making the trees more attractive $(51 \%)$.

As previously noted, people tended to prune smaller trees themselves but hired professionals to prune the larger ones (Table 3). Self-pruning occurred more frequently than did commercial pruning; on average, people pruned trees each year or every other year, but reported that they had commercial pruning performed at frequencies ranging from every other year to every five years.

The treatment of trees for insects or disease was much less commonly reported than was pruning. Only $32.5 \%$ of our sample ( 25 people of 77 who answered the question) reported having trees treated to prevent or overcome insects or disease. Resident and professional spraying followed the patterns noted with regards to tree removal and pruning: residents who had trees 
sprayed tended to take care of small trees themselves and contract with professionals to take care of the largest ones (Table 3). No difference was found in the frequency of treatment between resident-administered and professionally administered sprayings; such treatments were applied (as noted, over $66 \%$ of residents did not have trees treated) at frequencies ranging between yearly and every other year.

Growth potential of the Sacramento urban forest. Of 78 questionnaires returned with a property map, 24 indicated no room for new trees. Among the remaining 54 properties, there was room for 117 trees: 21 properties could take 1 tree, 18 had room for 2, 8 could take 3,3 had room for 4,2 had room for 5 trees, and 2 had room for 7 trees. This compares to the approximately 1,270 trees already present on the properties (a figure obtained by multiplying 16.3, the average number of trees per property in the survey, by 78 , the number of surveys returned with a property map). On average, each property potentially had room for 1.5 trees-an expansion rate of $9 \%$ for the residential urban forest. Of the potential 117 trees, residents wanted 91 , or $77.8 \%$ of them. Residents on only 7 properties out of 54 $(13 \%)$ that had room for new trees did not want them; 23 wanted 1 tree, 14 wanted 2, 5 wanted 3,2 wanted 4,1 wanted 5,1 wanted 6 , and 1 wanted 7 trees On average, each resident who had room for new trees wanted 1.7 trees. (This average does not conflict with the average of 1.5 potential trees because the latter average included properties without room for new trees, which the average of 1.7 desired trees does not.) It is important to note that this expressed interest came without a consideration of cost or effort, and no commitment was made by respondents to plant the trees they said they wanted. As a result, the actual growth potential of the Sacramento urban forest is bound to be somewhat less than reflected by the above numbers.

\section{Discussion}

On the basis of this study, several tentative conclusions can be advanced:

1. The high average number of trees per property (16.3), and the low average number of po- tential trees per property (1.5), indicate that residential properties in Sacramento will not be a major growth sector for the urban forest. If this is the case (and more work must be done to determine the representativeness of this sample), then the focus of tree planting efforts will need to shift back from residential areas and towards business and public areas. Given that business and industrial sections of a city are probably the most urbanized and least natural regions within it, the potential expansion of the urban forest is still considerable, and the impact of urban forestry will continue to be very significant. But urban forestry programs will have to meet new challenges to "green" these areas, not least of which will be the higher cost of planting (given the relative scarcity of open, uncemented ground in many urban downtown areas) and the difficulty of obtaining funds for such an effort.

Residents can be considered an "easier sell" than downtown business owners when it comes to tree planting. Residents have a vested interest in the attractiveness of their homes and turn to trees to enhance that attractiveness. This is borne out by the high percentage of potential trees in our study $(78 \%)$ that were desired by homeowners and the fact that over two-thirds of residents had added trees to their property after moving in. Business owners may be expected to take more of a "hard-nosed" attitude towards trees, wanting evidence of tangible benefits before investing in tree planting and maintenance. Future urban forestry efforts will probably have to focus on strengthening arguments in favor of private and public investment, document and publicize material benefits from urban forestry, and develop more cost-effective planting and stewardship programs.

2. The importance of comfort- and appearance-level factors in the decision to plant trees (the dominance of shade and aesthetics as motivators) over factors such as energy savings, privacy, and property values, or philosophical values such as ecological benefits, points the way towards creating a constituency for urban (in the future, downtown) forestry. Attempts to gain support from an urban population should probably direct attention to how much more comfortable 
and attractive parks and downtown streets would be if they had more trees. Arguments directed towards government officials or towards business owners should not only point out the direct economic benefits of planting (such as energy savings, cleaner air and, therefore, fewer health problems) but also make much of the fact that more comfortable, attractive streets, parks, and parking lots will draw people to them, and result in greater use, more potential customers, and probably safer cities (Jacobs 1993).

3. The patterns of tree planting and removal indicate that such activities tend to occur at the highest rate early in a resident's tenure in a home. This would seem to be a part of the personalizing process, of adapting the new home to one's own tastes. The target audience for residential tree planting appeals probably consists of new homeowners in the midst of landscaping their new property.

Urban forestry programs focus not only on getting trees planted, but on getting the right trees planted in the right places. A need exists to distribute information to people planting (or planning to plant) trees, to aid them in making more ecologically or economically beneficial decisions. Nonprofit tree planting organizations like the Sacramento Tree Foundation (STF) make information distribution a main goal, but only a small percentage of trees in our sample (less than 4\%) came from the STF. Information on tree selection and siting should be made available through nurseries and professional arborists. While issues of aesthetics and shade outweigh the more pragmatic issues of energy conservation and ecological benefit in planting decisions, one can hope that homeowners may be convinced to plant for both reasons-some trees purely for aesthetics and shade (which would contribute to energy savings), others for environmental reasons or other issues of public good. Maintenance information should also be made available, to better protect the investment in the urban forest.

4. Patterns of pruning, spraying, and tree removal demonstrate the role of convenience in maintenance behavior. Residents performed maintenance that was relatively easy to do, on smaller trees; that which was more difficult, or potentially dangerous, was left to professionalsor perhaps left undone. Note that professional pruning was reportedly less frequent than selfpruning. It is easy to imagine that many larger trees, or trees that are otherwise hard to maintain, are simply allowed to "fend for themselves." (Trees in $15 \%$ of the residences in our survey were reportedly never pruned.) This represents a potential wasted investment in the urban forest if the tree is not able to "fend for itself." It also creates a possible danger, from dead branches that are not pruned or large, weakened trees that might uproot in a storm. An article in the Sacramento Bee makes just this point: "The trees aren't getting regular care, the kind that can extend their lives and keep them from becoming hazards. Many street trees get no attention until someone calls to complain about them." The article further states, "Trees in a forest may live hundreds of years, but a city tree typically lives only a few decades" (Vogel 1996).

Research has shown that, given the enormous investment in tree planting, the cost of periodic pruning of large trees is small relative to the benefits produced (McPherson 1994). Further research is needed to quantify benefits and costs of investment in mature tree care. More study is also needed regarding the issue of maintenance, to discover what people know about types of maintenance required by trees and the overall importance of tree maintenance. Concerning pest and disease control, at least, $66 \%$ of households seemed to consider regular maintenance unnecessary. American urban forests have in the past been devastated by pests and disease (for example, Dutch elm disease). If trees are to thrive, and communities to benefit from them, residents must develop a greater awareness of maintenance issues.

\section{Conclusion}

The national parks and forests of the United States are deeply loved and visited by millions of people each year. Large sums of money are allocated for, and tens of thousands of foresters dedicated to, their preservation, maintenance, and enhancement. But the most commonly visited forest, the one with greatest potential for im- 
proving the quality of life for the average person, is given no such recognition. This is the urban forest.

Research has extensively documented benefits people can receive from the presence of nature in the everyday environment, but despite this, investment in the urban forest has been slow to materialize and quick to disappear in times of tight budgets. The result has been that the urban forest is primarily the province of individual residents who plant personal urban "groves" or stands of trees. If urban forests are to grow and thrive, and the documented benefits are to be reaped from them, homeowners will need to become part-time urban foresters and cities will need to develop policies and practices that are more "forest friendly."

Acknowledgements. This research was supported in part by funds provided by the Pacific Southwest Research Station, Forest Service, U.S. Department of Agriculture, in cooperation with the Western Center for Urban Forestry Research and Education. The authors would like to express their appreciation to Regina Adams, Annabel Chung, Richard Bagaoisan, Andrew Hertz, Vance Howard, Melissa Kaufman, Nina Luttinger, Robert Sommer, and Tin-Wah Wong.

\section{Literature Cited}

Akbari, H., S. Davis, S. Dorsano, J. Huang, and S. Winnett (Eds.). 1992. Cooling Our Communities: A Guidebook on Tree Planting and Light-Colored Surfacing. U.S. Environmental Protection Agency, Washington, DC.

Appleyard, D. 1980. Urban trees, urban forests: What do they mean? In Proceedings of the National Urban Forestry Conference. Nov. 1978:138-155. State University of New York Press, Syracuse, NY.

Arnold, H.F. 1980. Trees in Urban Design.Van Nostrand Reinhold, New York, NY.

Dwyer, J., E.G. McPherson, H. Schroeder, and R. Rowntree. 1992. Assessing the benefits and costs of the urban forest. J. Arboric. 18:227-234.

Heisler, G. 1986. Energy savings with trees. J. Arboric. 15:113-125.

Hull, R. Bruce, IV. 1992. How the public values urban forests. J. Arboric. 18:98-101.

Jacobs, J. 1993. The Death and Life of Great American Cities. Random House, New York, NY.
Kaplan, S. 1987. Aesthetics, affect and cognition: Environmental preference from an evolutionary perspective. Environ. Behav. 19:3-32.

Kaplan, R., and S. Kaplan. 1989. The Experience of Nature: A Psychological Perspective. Cambridge

McPherson, E.G. 1994. Benefits and costs of tree planting and care in Chicago. In McPherson, E.G., D.J. Nowak, and R.A. Rowntree (Eds.). Chicago's Urban Forest Ecosystem: Results of the Chicago Urban Forest Climate Project. USDA For. Serv. Northeast. For. Exp.Sta. Gen. Tech. Rpt. NE-GTR186.

McPherson, E.G., and J.R. Simpson. 1995. Shade trees as a demand-side resource. Home Energy. March/April 1995:11-17.

Nowak, D.J. 1994. Air pollution removal by Chicago's urban forest. In McPherson, E.G., D.J. Nowak, and R.A. Rowntree (Eds.). Chicago's Urban Forest Ecosystem: Results of the Chicago Urban Forest Climate Project. USDA For. Serv. Northeast. For. Exp. Sta. Gen. Tech. Rpt. NE-GTR-186.

Payne, B.R., and S. Strom. 1975. The contribution of trees to the appraisal value of unimproved residential land. Valuation 22:36-45.

Relf, D. 1981. Dynamics of horticultural therapy. Rehabil. Lit. 42:147-160.

Schroeder, H.W. 1989. Environment, behavior, and design research on urban forests, pp. 87-117. In Zube, E.H., and G.T. Moore (Eds.). Advances in Environment, Behavior, and Design, vol. 2. Plenum Press, New York, NY.

Sheets, V.L., and C.D. Manzer. 1991. Affect, cognition, and urban vegetation: Some effects of adding trees along city streets. Environ. Behav. 23:285-304.

Smardon, R. 1988. Perception and aesthetics of the urban environment: Review of the role of vegetation. Landsc. Urb. Plann. 15:85-106.

Sommer, R., F. Learey, and J. Summit. 1993. The social benefits of resident involvement in tree planting. J. Arboric. 20:170-175.

Sommer, R., and J. Summit. 1995. An exploratory study of preferred tree form. Environ. Behav. 27:540-557.

Summit, J., and R. Sommer. 1998. Urban tree-planting programs: A model for encouraging environmentally protective behavior. Atmosph. Environ. 32:1-5.

Ulrich, R.S. 1981. Natural versus urban scenes: Some psychophysiological effects. Environ. Behav. 13:523-556.

Ulrich, R.S. 1984. View through a window may influence recovery from surgery. Science 224 : 420-421. 
Vogel, N. 1996. A legacy in danger: Lack of care imperils capital's aging trees. Sacramento Bee, May $12, \mathrm{~A} 1$.

Williamson, R.D. 1973. Bird-and peopleneighborhoods. Nat. Hist. 82: 55-57.

'Department of Psychology

University of California

Davis, CA 95616

${ }^{2}$ Pacific Southwest Research Station

USDA Forest Service

c/o Department of Environmental Horticulture

University of California

Davis, CA 95616

Résumé. Les propriétés résidentielles de Sacramento en Californie ont été inventoriés et des questionnaires ont été soumis aux résidents pour s'informer sur leur motivation à planter des arbres et sur l'étendue et la fréquence de leur entretien. Ces enquêtes ont indiqué que : 1) la plupart des résidents plantent des arbres sur leur propriété, 2) les secteurs résidentiels sont densément plantés en général, 3 ) les motifs de confort et d'apparence interviennent plus dans la décision de planter des arbres que ceux reliés à l'économie d'énergie, les bénéfices environnementaux ou à l'intimité des lieux, 4) la plantation des arbres tend à être plus tôt et plus importante chez les résidents propriétaires de leur maison, et 5) la commodité est un facteur majeur de prédiction des types d'entretien prodigués par les résidents par rapport à ceux fournis par les entrepreneurs.

Zusammenfassung. In Sacramento, CA wurden Standortuntersuchungen auf bebautem Grundstückseigentum durdchgeführt, indem die Besitzer darüber befragt wurden, ob sie zusätzliche Baumpflanzungen auf ihrem Grundstück ausgeführt haben, worin die Motivation bestand und ob und wie intensiv sie den Baumbestand pflegen. Diese Erhebungen zeigten:

1. Die meisten Eigentümer pflanzen Bäume auf ihrem Grundstück.

2. Die bebauten Flächen sind relative dicht bepflanzt.

3. Kriterien, wie Komfort und äußere Erscheinung spielen bei der Entscheidung Bäume zu pflanzen, eine Größere Rolle als Überlegungen zur Energieeinsparung, Umweltverbesserung oder Privatsphäre.

4. Die Baumpflanzung wurde in den frühen Jahren nach dem Einzug durchgeführt.

5. Die Bequemlichkeit ist ein starker Indikator f:ur die Art der Baumpflege, die durch die Besitzer im Gegensatz zu Fachfirmen ausgehührt wird. 